\title{
EVALUASI KONDISI PERMUKAAN JALAN DENGAN MENGGUNAKAN METODE BINA MARGA PADA JALAN GAJAH MADA KOTA TARAKAN PROVINSI KALIMANTAN UTARA
}

\section{EVALUATION OF ROAD SURFACE CONDITION USING BINA MARGA METHOD ON GAJAH MADA ROAD IN TARAKAN CITY NORTH KALIMANTAN PROVINCE}

\author{
Muhammad Djaya Bakri \\ Jurusan Teknik Sipil, Fakultas Teknik, Universitas Borneo Tarakan \\ Jalan Amal Lama Nomor 1, Tarakan \\ Email: jayabakri@gmail.com
}

\begin{abstract}
ABSTRAK
Jalan Gajah Mada mempunyai peranan penting dalam menggerakkan perekonomian kota Tarakan dan merupakan akses utama menuju kawasan Pasar Gusher dan Pelabuhan Tengkayu II. Karena perannya strategis, maka diperlukan kualitas jalan yang dapat memberikan keamanan dan kenyamanan bagi pengguna jalan, sehingga dipandang perlu melakukan evaluasi tingkat kerusakannya untuk dapat menentukan urutan prioritas pemeliharaannya. Hasil indentifikasi lapangan diperoleh 9 tipe kerusakan yaitu: kerusakan retak kulit buaya seluas $571,00 \mathrm{~m}^{2}$, berikutnya retak memanjang/retak pinggir $\left(879,00 \mathrm{~m}^{2}\right)$, retak melintang $\left(380,36 \mathrm{~m}^{2}\right)$, retak acak $\left(514,80 \mathrm{~m}^{2}\right)$, alur $\left(137,10 \mathrm{~m}^{2}\right)$, tambalan dan lubang $\left(1.413,42 \mathrm{~m}^{2}\right)$, pelepasan butir $\left(398,64 \mathrm{~m}^{2}\right)$, kegemukan $\left(375,20 \mathrm{~m}^{2}\right)$, dan amblas $\left(251,04 \mathrm{~m}^{2}\right)$. Perhitungan nilai kondisi jalan dengan metode Bina Marga diperoleh urutan prioritas 4 untuk penanganan jalan sisi kiri berupa program pemeliharaan berkala, dan urutan prioritas 3 pada jalan sisi kanan berupa program pemeliharaan peningkatan jalan. Usulan perbaikan dari hasil studi ini untuk Jalan Gajah Mada adalah program peningkatan jalan berupa kegiatan penambahan lapis permukaan perkerasan (overlay).
\end{abstract}

Kata Kunci : Kondisi Permukaan Jalan; Perkerasan Lentur; Metode Bina Marga

\begin{abstract}
The Gajah Mada Street has a important role in driving the economy of the Tarakan city and is the main access to the Gusher Market and Tengkayu II Harbor. Because of its strategic role, road quality is needed that can provide safety and comfort for road users, so it is deemed necessary to evaluate the level of damage to determine the order of priority for maintenance. Field identification results obtained 9 types of damage, namely: aligator cracking covering an area of $571.00 \mathrm{~m}^{2}$, subsequent damage is longitudinal/edge cracking $\left(879.00 \mathrm{~m}^{2}\right)$, transverse cracking $\left(380.36 \mathrm{~m}^{2}\right)$, random cracking $\left(514.80 \mathrm{~m}^{2}\right)$, rutting $\left(137.10 \mathrm{~m}^{2}\right)$, patching and potholes $\left(1,413.42 \mathrm{~m}^{2}\right)$, ravelling $\left(398.64 \mathrm{~m}^{2}\right)$, bleeding $\left(375.20 \mathrm{~m}^{2}\right)$, and depression $\left(251.04 \mathrm{~m}^{2}\right.$ ). Calculation of the value of road conditions by the Bina Marga method obtained priority order 4 for handling the left side of the road in the form of a periodic maintenance program, and priority order 3 on the right side of the road in the form of a road betterment program. The proposed improvement from the results of this study for The Gajah Mada Street is a road betterment program in the form of activities to add layers of pavement (overlay).
\end{abstract}

Keywords: Road Surface Conditions; Bending; Bina Marga Method 


\section{PENDAHULUAN}

Prasarana transportasi jalan yang setiap waktu terbebani oleh volume lalu lintas yang tinggi dan berulang-ulang akan menyebabkan terjadinya penurunan kualitas dari perkerasan tersebut, sehingga tidak aman dan tidak nyaman untuk dilalui. Evaluasi kondisi perkerasan jalan sangat penting dilakukan untuk mengetahui seberapa tingkat kerusakan yang terjadi pada suatu ruas jalan. Untuk mengetahui tingkat kerusakan dan usulan perbaikan suatu jalan diperlukan metode yang dapat memberikan pedoman dalam melaksanakan survei kondisi perkerasan jalan secara visual, analisis kerusakan perkerasan, dan mengklasifikasikannya.

Ada beberapa metode pendekatan yang dapat digunakan untuk menilai kondisi jalan seperti metode Bina Marga, metode PCI (Pavement Condition Index), dan metode PDI (Pavement Distress Index). Metode Bina Marga lazim digunakan untuk penilaian kondisi jalan, karena penggunaannya di lapangan tidak memerlukan peralatan khusus, hanya berbasis pengamatan visual dan pengukuran kerusakan di lapangan yang akan mendapatkan tipe kerusakan dan tingkat keparahan kerusakan.

Dalam penelitian ini menggunakan metode Bina Marga untuk menilai kondisi Jalan Gajah Mada Kota Tarakan Provinsi Kalimantan Utara. Jalan ini mempunyai peranan sangat penting dalam menggerakkan perekonomian dan mendukung kegiatan sosial masyarakat. Jalan ini merupakan jalan provinsi dengan konstruksi perkerasan lentur (flexible pavement), dengan fungsi sebagai jalan kolektor sekunder di kawasan peniagaan kota Tarakan dan merupakan akses utama menuju kawasan perdagangan Pasar Gusher dan Pelabuhan Tengkayu II seperti ditampilkan pada Gambar 1.

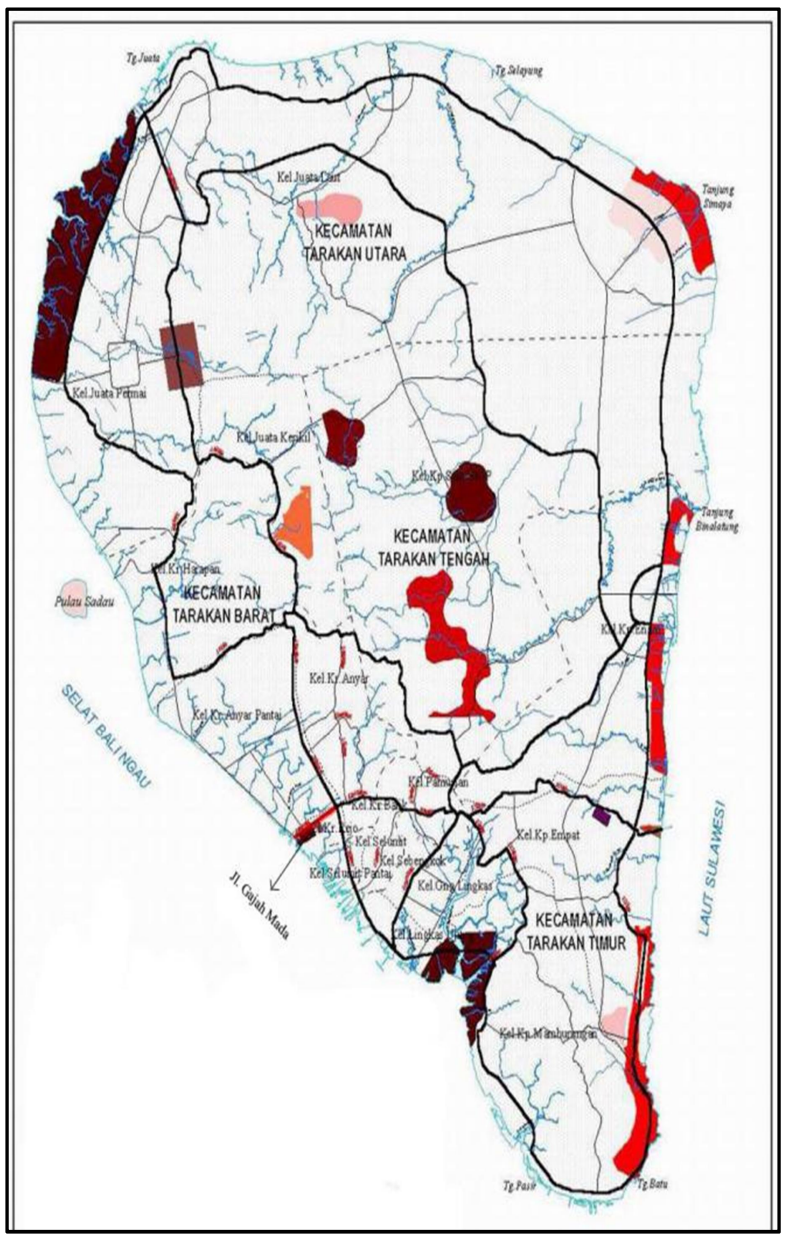

\section{Gambar 1. Lokasi Jalan Gajah Mada Kota Tarakan}

Karena letak jalannya yang sangat strategis sebagai penunjang berjalannya roda ekonomi kota Tarakan, maka diperlukan kualitas jalan yang dapat memberikan keamanan dan kenyamanan bagi pengguna jalan, sehingga dipandang perlu melakukan evaluasi tingkat kerusakannya untuk dapat menentukan urutan prioritas pemeliharaan jalannya.

\section{METODE PENELITIAN}

Metode Bina Marga ini banyak dipergunakan dalam penelitian untuk menilai kondisi jalan dan hasilnya dipergunakan untuk usulan perbaikaan jalannya. Beberapa penelitian terdahulu yang telah dilaksanakan oleh Bolla 
(2012), Saputro (2014), Daryoto et al (2015), Wicaksono dan Mahardi (2018), Suwandi et al (2018), Bakri (2019) dijadikan referensi dalam penelitian ini, disamping menggunakan rujukan dari peraturan-peraturan dan pedoman yang terkait.

\section{a. Penyebab Kerusakan Jalan}

Menurut Sukirman (1999) dalam Bakri (2019) bahwa kerusakan pada konstruksi perkerasan jalan dapat disebabkan hal sebagai berikut:

1. Arus lalulintas, dapat berupa peningkatan dan repetisi beban.

2. Air, yang dapat berupa air hujan, sistem drainase yang tidak baik, naiknya air akibat kapilaritas.

3. Material konstruksi perkerasan, dalam hal ini disebabkan oleh sifat material itu sendiri atau dapat pula disebabkan oleh sistem pengelolaan bahan yang tidak baik.

4. Iklim, Indonesia beriklim tropis dimana suhu udara dan curah hujan umumnya tinggi, yang merupakan salah satu penyebab kerusakan jalan.

5. Kondisi tanah dasar yang tidak stabil, kemungkinan disebabkan oleh sistem pelaksanaan yang kurang baik, atau dapat juga disebabkan oleh sifat tanah yang memang jelek.

6. Proses pemadatan lapisan diatas tanah yang kurang baik.

\section{b. Jenis Kerusakan Jalan}

Untuk mengetahui kondisi suatu perkerasan jalan, perlu dilaksanakan survei kondisi jalan untuk mendapatkan informasi yang dapat digunakan dalam analisis untuk menetapkan metode perbaikan dan prioritas program pemeliharaannya.

Jenis kerusakan jalan perkerasan lentur menurut Bina Marga (1995) umumnya dklasifikasikan sebagai berikut:

1. Deformasi, terjadi perubahan permukaan jalan dari profil aslinya sesudah pembangunan, berupa: bergelombang, alur, amblas, sungkur, mengembang, benjol dan turun.

2. Retak terjadi akibat regangan tarik pada permukaan aspal melebihi dari regangan tarik maksimum, terdiri dari retak: memanjang, melintang, diagonal, reflektif, blok, kulit buaya dan bentuk bulan sabit.

3. Kerusakan tekstur permukaan, seperti: butiran lepas, kegemukan, agregat licin, terkelupas dan stripping.

4. Kerusakan lubang, tambalan dan persilangan jalan rel.

5. Kerusakan di pinggir perkerasan: pinggir retak/pecah dan bahu turun.

\section{c. Jenis Preservasi Jalan Raya}

Jenis pemeliharaan jalan yang digunakan di Indonesia menurut Peraturan Menteri Pekerjaan Umum Nomor: 13/PRT/M/2011 Tentang Tata Cara Pemeliharaan Jalan dan Penilikan Jalan, ada empat bentuk pemeliharaan jalan yaitu:

1. Pemeliharaan rutin. Merupakan kegiatan merawat serta memperbaiki kerusakan-kerusakan yang terjadi pada ruas-ruas jalan dengan kondisi pelayanan mantap.

2. Pemeliharaan Berkala. Merupakan kegiatan penanganan pencegahan terjadinya kerusakan yang lebih luas dan setiap kerusakan yang diperhitungkan dalam desain agar penurunan kondisi jalan dapat dikembalikan pada kondisi kemantapan sesuai dengan rencana.

3. Rehabilitasi Jalan. Rehabilitasi jalan adalah kegiatan penanganan 
pencegahan terjadinya kerusakan yang luas dan setiap kerusakan yang tidak diperhitungkan dalam desain, yang berakibat menurunnya kondisi kemantapan pada bagian tertentu dari suatu ruas jalan dengan kondisi rusak ringan, agar penurunan kondisi kemantapan tersebut dapat dikembalikan pada kondisi kemantapan sesuai dengan rencana.

4. Rekonstruksi Jalan. Rekonstruksi adalah peningkatan struktur yang merupakan kegiatan penanganan untuk dapat meningkatkan kemampuan bagian ruas jalan yang dalam kondisi rusak berat agar bagian jalan tersebut mempunyai kondisi mantap kembali sesuai dengan umur rencana yang ditetapkan, dilakukan pada ruas jalan dengan kondisi rusak berat.

\section{d. Evaluasi Kerusakan Jalan Dengan Metode Bina Marga}

Pemilihan bentuk preservasi jalan yang tepat dilakukan dengan melakukan penilaian terhadap kondisi permukaan jalan berdasarkan pada jenis kerusakan yang ditetapkan dengan metode yang digunakan. Pada metode Bina Marga (1990), jenis kerusakan yang perlu diperhatikan saat melakukan survei adalah kekasaran permukaan, lubanglubang, tambalan, retak-retak, alur dan amblas. Penentuan nilai kondisi jalan dilakukan dengan menjumlahkan setiap angka dan nilai untuk masing-masing keadaan kerusakan.

Prosedur survei dan analisis data untuk penentuan nilai urutan prioritas preservasi jalan dengan Metode Bina Marga adalah sebagai berikut:

1. Konfirmasi Klasifikasi Fungsi dan Kelas Jalan. Untuk memastikan klasifikasi, fungsi dan kelas jalan yang akan ditangani diperlukan koordinasi dengan Dinas Pekerjaan Umum setempat untuk ketepatan penanganannya.

2. Menghitung LHR untuk jalan yang di survey dan tetapkan nilai kelas lalu lintas untuk pemeliharaan jalan dengan menggunakan Tabel 1.

Tabel 1. Kelas Lalu Lintas Untuk Pekerjaan Pemeliharaan

\begin{tabular}{|c|c|}
\hline $\begin{array}{c}\text { Kelas } \\
\text { Lalu Lintas }\end{array}$ & $\begin{array}{c}\text { Lalu Lintas Harian Rata- } \\
\text { Rata } \\
\text { (LHR) }\end{array}$ \\
\hline 0 & $<20$ \\
\hline 1 & $20-50$ \\
\hline 2 & $50-200$ \\
\hline 3 & $200-500$ \\
\hline 4 & $500-2.000$ \\
\hline 5 & $2.000-5.000$ \\
\hline 6 & $5.000-20.000$ \\
\hline 7 & $20.000-50.000$ \\
\hline 8 & $>50.000$ \\
\hline
\end{tabular}

Sumber: TPPPJK No. 018/T/BNKT/1990

3. Menyajikan hasil survey dalam bentuk tabel dan mengelompokkan data sesuai dengan jenis kerusakan.

4. Melakukan penilaian terhadap setiap kerusakan berdasarkan parameter yang disajikan pada Tabel 2.

Tabel 2. Penilaian Kondisi

Kerusakan Jalan

\begin{tabular}{|c|c|c|}
\hline \multicolumn{2}{|l|}{ Retak-retak (Cracking) } \\
\hline Tipe & Angka \\
\hline E. & Buaya & 5 \\
\hline D. & Acak & 4 \\
\hline C. & Melintang & 3 \\
\hline B. & Memanjang & 2 \\
\hline A. & Tidak Ada & 1 \\
\hline Lebar & $>2 \mathrm{~mm}$ & Angka \\
\hline D. & $>$ & 3 \\
\hline C. & $1-2 \mathrm{~mm}$ & 2 \\
\hline B. & $<1 \mathrm{~mm}$ & 1 \\
\hline A. & Tidak Ada & 0 \\
\hline Jumlah Kerusakan (Luas) & Angka \\
\hline D. & $>30 \%$ & 2 \\
\hline C. & $10-30 \%$ & 1 \\
\hline B. & $<10 \%$ & \\
\hline
\end{tabular}


JURNAL BORNEO SAINTEK

Volume 3, Nomor 1, April 2020

e-ISSN 2599-3313

p-ISSN 2615-434X

\begin{tabular}{|c|c|c|}
\hline A. & Tidak Ada & 0 \\
\hline \multicolumn{3}{|c|}{ Alur (Rutting) } \\
\hline \multicolumn{2}{|c|}{ Kedalaman } & Angka \\
\hline E. & $>20 \mathrm{~mm}$ & 7 \\
\hline D. & $11-20 \mathrm{~mm}$ & 5 \\
\hline C. & $6-10 \mathrm{~mm}$ & 3 \\
\hline B. & $0-5 \mathrm{~mm}$ & 1 \\
\hline A. & Tidak Ada & 0 \\
\hline \multicolumn{3}{|c|}{ Tambalan \& Lubang (Patching \& Pothole) } \\
\hline \multicolumn{2}{|c|}{ Luas } & Angka \\
\hline D. & $>30 \%$ & 3 \\
\hline C. & $20-30 \%$ & 2 \\
\hline B. & $10-20 \%$ & 1 \\
\hline A. & $<10 \%$ & 0 \\
\hline \multicolumn{3}{|c|}{ Kekasaran Permukaan (Surface Texture) } \\
\hline \multicolumn{2}{|c|}{ Tipe } & Angka \\
\hline $\mathrm{E}$. & Disintegration & 4 \\
\hline D. & Pelepasan Butir & 3 \\
\hline C. & Rough (Hungry) & 2 \\
\hline B. & Fatty & 1 \\
\hline A. & Close Texture & 0 \\
\hline \multicolumn{3}{|c|}{ Amblas (Depression) } \\
\hline \multicolumn{2}{|c|}{ Luas } & Angka \\
\hline D. & $>5 / 100 \mathrm{~m}$ & 4 \\
\hline C. & $2-5 / 100 m$ & 2 \\
\hline B. & $0-2 / 100 m$ & 1 \\
\hline A. & Tidak Ada & 0 \\
\hline
\end{tabular}

Sumber: TPPPJK No. 018/T/BNKT/1990

5. Penentuan nilai kondisi jalan dengan menjumlahkan setiap angka untuk semua jenis kerusakan, berdasarkan Tabel 3.

Tabel 3. Nilai Kondisi Jalan

\begin{tabular}{|c|c|}
\hline \multicolumn{2}{|c|}{ Penilaian Kondisi } \\
\hline Total Angka Kerusakan & Nilai \\
\hline $26-29$ & 9 \\
\hline $22-25$ & 8 \\
\hline $19-21$ & 7 \\
\hline $16-18$ & 6 \\
\hline $13-15$ & 5 \\
\hline $10-12$ & 4 \\
\hline $7-9$ & 3 \\
\hline $4-6$ & 2 \\
\hline $0-3$ & 1 \\
\hline
\end{tabular}

Sumber: TPPPJK No. 018/T/BNKT/1990

6. Penentuan Urutan Prioritas (UP) pemeliharaan jalan dengan menggunakan rumus yang tercantum dalam Tata Cara Penyusunan Program Pemeliharaan Jalan Kota No. 018/T/BNKT/1990 sebagai berikut:

$$
\begin{aligned}
U P= & 17-(\text { Kelas LHR + Nilai } \\
& \text { Kondisi Jalan })
\end{aligned}
$$

Available online at www.jurnal.borneo.ac.id Halaman 07-17

Hasil perhitungan Urutan Prioritas (UP) tersebut mepresentasikan rekomendasi program preservasi jalan sebagai berikut:

Urutan Prioritas 0 - 3, menandakan jalan masuk dalam program peningkatan/rehabilitasi jalan.

Urutan Prioritas 4 - 6, menandakan jalan masuk dalam program pemeliharaan berkala.

Urutan Prioritas 7, menandakan jalan masuk dalam program pemeliharaan rutin.

\section{e. Alur Penelitian}

Alur penelitian digambarkan dalam bentuk flow chart untuk mempermudah sistematika penelitian. Bagan flow chart penelitian seperti ditampilkan pada Gambar 2.

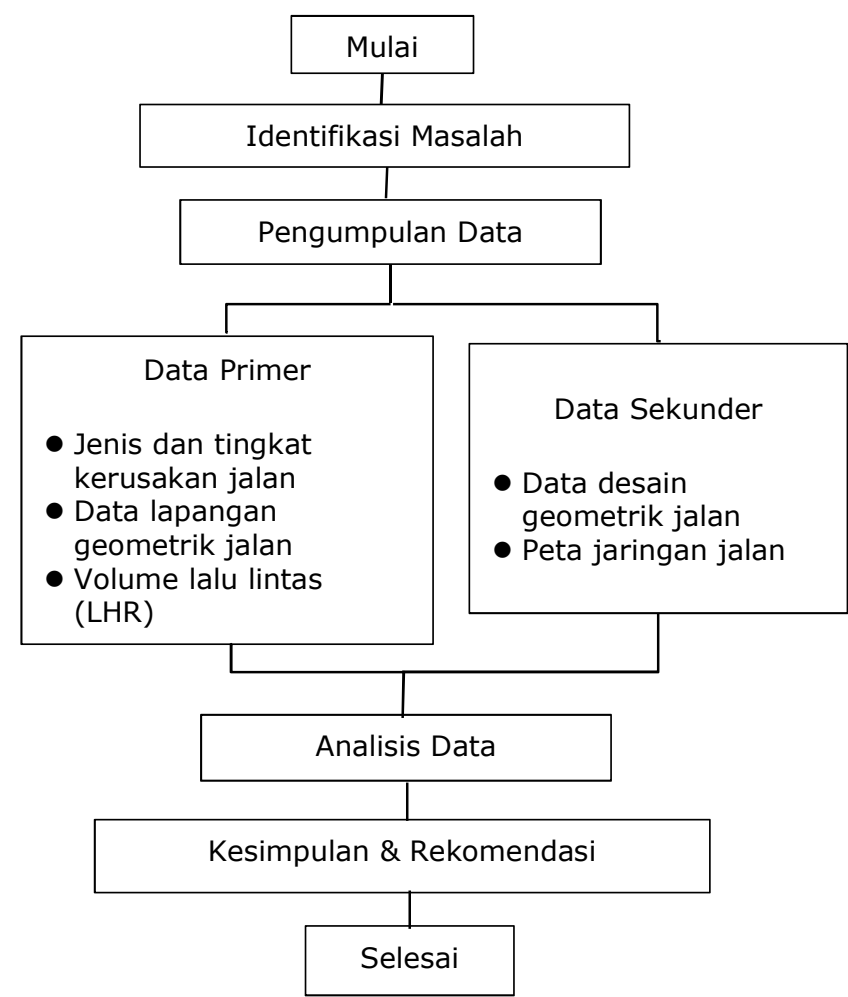

Gambar 2. Flow Cart Penelitian

HASIL DAN PEMBAHASAN

a. Data Geometrik Jalan

Jalan Gajah Mada di Kota Tarakan merupakan jalan provinsi dengan 
JURNAL BORNEO SAINTEK

Volume 3, Nomor 1, April 2020

e-ISSN 2599-3313

p-ISSN 2615-434X

kriteria desain geometrik seperti disajikan pada Tabel 4.

Tabel 4. Data Desain Geometrik Jalan Gajah Mada Kota Tarakan

\begin{tabular}{|l|c|c|}
\hline \multicolumn{1}{|c|}{ Uraian } & Satuan & Keterangan \\
\hline Fungsi Jalan & - & Kolektor Sekunder \\
\hline Kelas Jalan & - & IIIB \\
\hline Status Jalan & - & Jalan Provinsi \\
\hline Tipe Medan & - & Datar \\
\hline Tipe Jalan & - & $2 / 2$ D \\
\hline Jumlah Lajur & - & 2 \\
\hline Jumlah Jalur & Per lajur & 2 \\
\hline Lebar Lajur & Meter & 3,5 \\
\hline Lebar Jalan & Meter & 12 \\
\hline V Rencana & KM/Jam & $40-50$ \\
\hline Panjang Jalan & KM & 0,928 \\
\hline
\end{tabular}

Jalan Gajah Mada ini dengan pangkal jalan berada pada perempatan jalan nasional dan ujung jalan terhubung dengan area Pelabuhan Tengkayu 2 seperti ditunjukkan pada Gambar 3 dan Gambar 4.

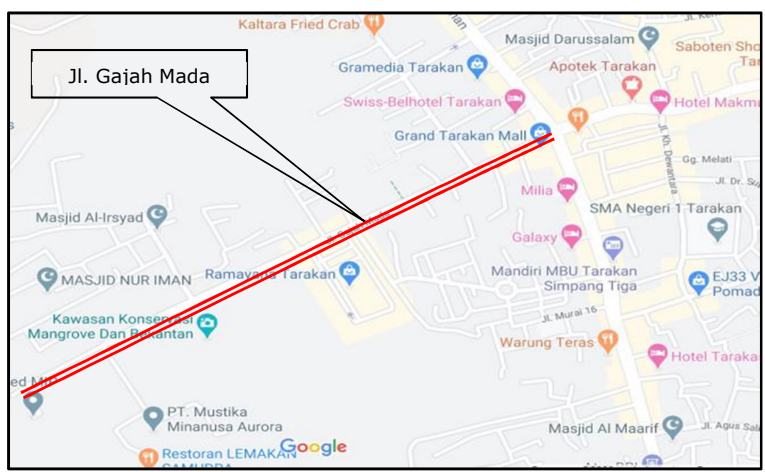

Gambar 3. Lokasi Jalan Gajah Mada (Sumber: GoogleMaps)

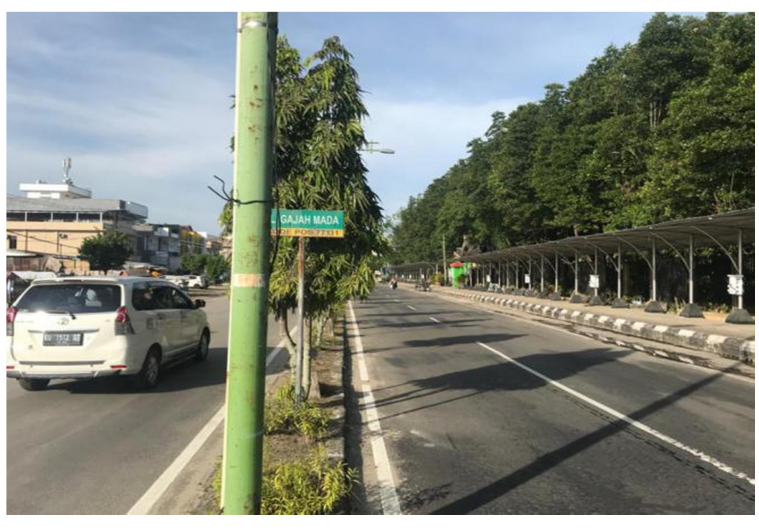

Gambar 4. Ujung Jalan Gajah Mada (Sumber: Survei Lapangan, 2020)
Available online at www.jurnal.borneo.ac.id Halaman 07-17

\section{b. Data Volume Lalu Lintas}

Survey volume lalu lintas yang melewati ruas Jalan Gajah Mada dilakukan secara bersamaan pada 2 pos pengamatan untuk dua arah sesuai tipe jalan dua arah terbagi $(2 / 2 \mathrm{D})$. Survei dilaksanakan selama 2 hari yaitu hari Sabtu dan Minggu yang mewakili hari sibuk pada kawasan perekonomian Kota Tarakan ini yang mempunyai frekwensi lalulintas relatif padat (tanggal 22 sampai dengan 23 Pebruari 2020). Survey dilaksanakan selama 15 jam, dimulai jam 05.00 pagi hingga jam 20.00. Hasil survey lalu lintas seperti disajikan pada Tabel 5.

\section{Tabel 5. Lalu Lintas Harian Rata-Rata}

\begin{tabular}{|c|c|c|c|c|c|}
\hline \multirow[b]{2}{*}{ Hari } & \multirow{2}{*}{$\begin{array}{c}\text { Pos } \\
\text { Penga- } \\
\text { matan }\end{array}$} & \multicolumn{4}{|c|}{ Rata-rata Kendaraan Per Hari } \\
\hline & & $\begin{array}{c}M C \\
(0,5)\end{array}$ & $\operatorname{LV}(1,0)$ & $\begin{array}{c}\mathrm{HV} \\
(1,3)\end{array}$ & Total \\
\hline \multirow{2}{*}{ Sabtu } & 1 & 3.464 & 1.145 & 305 & 4.914 \\
\hline & 2 & 3.504 & 1.084 & 284 & 4.872 \\
\hline \multirow{2}{*}{ Minggu } & 1 & 3.584 & 1.162 & 344 & 5.090 \\
\hline & 2 & 3.634 & 1.088 & 324 & 5.046 \\
\hline \multicolumn{2}{|c|}{ Jumlah } & 14.186 & 4.479 & 1.257 & 19.922 \\
\hline \multicolumn{2}{|c|}{ Rata-rata } & 3.546 & 1.120 & 314 & 4.981 \\
\hline \multicolumn{2}{|c|}{$\begin{array}{l}\text { Rata-rata } \\
\text { (smp/hari) }\end{array}$} & 1.773 & 1.120 & 408 & 3.301 \\
\hline
\end{tabular}

\section{c. Identifikasi Kondisi Kerusakan Jalan}

Identifikasi kondisi jalan pada sepanjang ruas Jalan Gajah Mada dilaksanakan dengan mengacu pada Petunjuk Teknis Perencanaan dan Penyusunan Program Jalan Kabupaten No. 77/KPTS/Db/1990. Ruas jalan Gajah Mada memiliki panjang jalan sebesar 0,928 KM, dan lebar masing-masing lajur adalah 3,50 meter, sehingga lebar jalur 2 x lajur menjadi 7,0 meter. Untuk luasan seluruh segmen jalan yang ditinjau untuk 1 lajur adalah sebesar $6.496 \mathrm{~m}^{2}$.

Kerusakan retak kulit buaya, memanjang, melintang dan retak acak merupakan jenis kerusakan yang banyak ditemui pada kedua sisi sepanjang ruas jalan. 


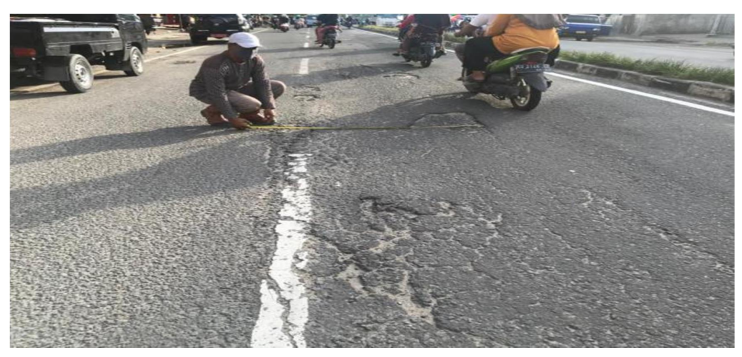

Gambar 5. Kerusakan Retak Kulit Buaya, Retak Memanjang, Retak Acak (Sumber: Survei Lapangan, 2020)

Pada sisi kiri ruas Jalan Gajah Mada terdapat retak dengan berbagai tipe seluas $1.059,69 \mathrm{~m}^{2}$ atau hampir sebesar $16,27 \%$ dari luasan permukaan ruas jalan sisi kirinya. Sedangkan pada sisi kanannya juga terdapat retak yang cukup besar yaitu seluas $867,08 \mathrm{~m}^{2}$ atau sebesar $13,35 \%$ dari luasan sisi jalannya. Kerusakan lubang dan tambalan merupakan jenis kerusakan yang berikutnya dominan terdapat pada kedua sisi ruas jalan yang ditinjau. Pada sisi kiri ruas Jalan Gajah Mada terdapat retak lubang sebanyak 43 buah atau titik total luas sebesar $349,56 \mathrm{~m}^{2}$ atau hampir sebesar $5,38 \%$ dari luasan permukaan ruas jalan sisi kirinya. Retak tambalan terdapat pada 18 titik, dengan luasan sebesar $314,80 \mathrm{~m}^{2}$ (4,85\% dari luasan segmen jalan sisi kiri). Sedangkan pada sisi kanannya juga terdapat retak lubang pada 44 titik dengan luasan total sebesar 284,26 $\mathrm{m}^{2}$ atau sebesar $4,38 \%$ dari luasan sisi jalannya.

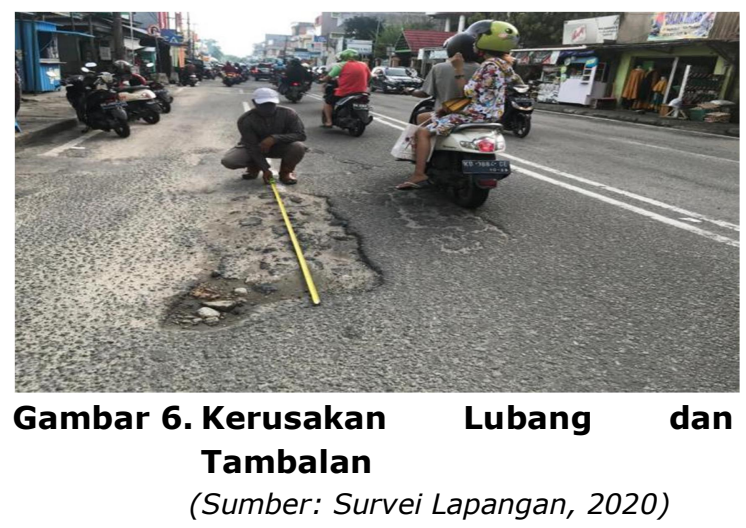

Kerusakan jalan yang berikutnya terdapat pada Jalan Gajah Mada adalah kekasaran permukaan dengan pelepasan butir, kegemukan dan pemisahan agregat. Pada sisi kiri ruas Jalan Gajah Mada terdapat retak kekasaran permukaan tersebut dengan luas sebesar 411,24 $\mathrm{m}^{2}$ atau hampir sebesar $6,33 \%$ dari luasan permukaan ruas jalan sisi kirinya. Pada sisi kanan terdapat luasan retak kekasaran permukaan tersebut dengan luasan sebesar 362,60 $\mathrm{m}^{2}$ atau sebesar $5,58 \%$ dari luasan sisi jalannya.

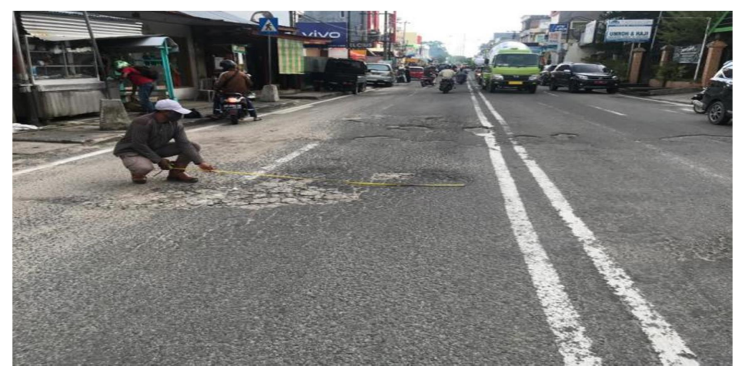

Gambar 7. Kerusakan Pelepasan Butir, Kegemukan, dan Pemisahan Agregat

(Sumber: Survei Lapangan, 2020)

Pada kedua sisi jalan yang disurvey, terdapat juga kerusakan retak pinggir memanjang pada beberapa titik disertai amblas pada sisi luar badan jalan dan pelepasan butir.

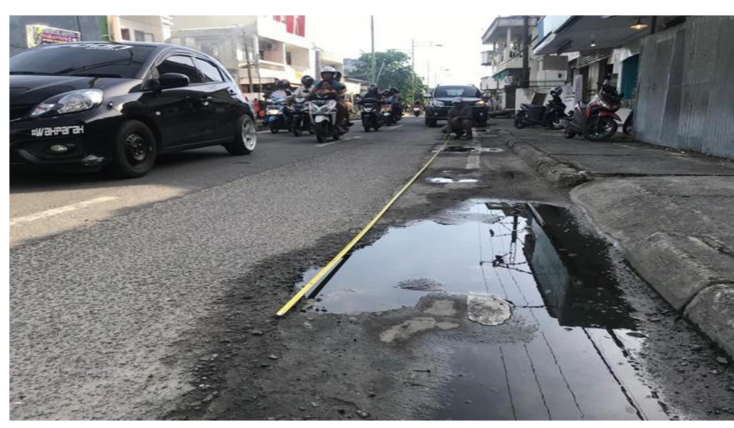

Gambar 8. Kerusakan Retak Pinggir (Sumber: Survei Lapangan, 2020)

Kerusakan amblas, terjadi alur memanjang disertai pelepasan butir terdapat juga pada area tengah jalur jalan pada beberapa titik kedua sisi sepanjang ruas jalan. Total kerusakan 
JURNAL BORNEO SAINTEK

Volume 3, Nomor 1, April 2020

e-ISSN 2599-3313

p-ISSN 2615-434X

tipe amblas dan alur pada kedua sisi ruas jalan mencapai $5,97 \%$ dari total luasan segmen jalan atau seluas 388,14 $\mathrm{m}^{2}$.

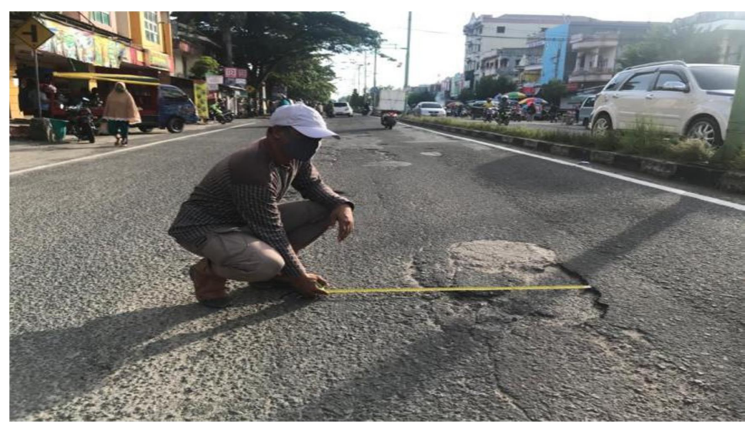

Gambar 9. Kerusakan Amblas, Alur (Sumber: Survei Lapangan, 2020)

Hasil survey kondisi kerusakan jalan untuk masing-masing jalur ruas Jalan Gajah Mada disajikan pada Tabel 6 dan Tabel 7.

\section{Tabel 6. Hasil Survey Identifikasi Kondisi Sisi Kiri Jalan Gajah Mada}

\begin{tabular}{|c|c|c|}
\hline Tipe Kerusakan & $\begin{array}{l}\text { Volume } \\
\text { kerusakan }\end{array}$ & $\begin{array}{c}\text { Prosentase luas } \\
\text { kerusakan dari } \\
\text { luas Jalur } \\
\left(6.496 \mathrm{~m}^{2}\right)\end{array}$ \\
\hline $\begin{array}{l}\text { Retak Kulit Buaya } \\
\text { (lebar > } 2 \mathrm{~mm} \text { ) }\end{array}$ & $424,20 \mathrm{~m}^{2}$ & $6,53 \%$ \\
\hline $\begin{array}{l}\text { Retak Memanjang / } \\
\text { Retak Pinggir } \\
(\text { lebar > } 2 \mathrm{~mm})\end{array}$ & $214,24 \mathrm{~m}^{2}$ & $3,30 \%$ \\
\hline $\begin{array}{l}\text { Retak Melintang } \\
\text { (lebar > } 2 \mathrm{~mm} \text { ) }\end{array}$ & $186,18 \mathrm{~m}^{2}$ & $2,87 \%$ \\
\hline $\begin{array}{l}\text { Retak Acak } \\
(\text { lebar > } 2 \mathrm{~mm} \text { ) }\end{array}$ & $232,34 \mathrm{~m}^{2}$ & $3,58 \%$ \\
\hline \multirow{2}{*}{$\begin{array}{l}\text { Alur (kedalaman } 6 \text { - } \\
10 \mathrm{~mm} \text { ) }\end{array}$} & 6 buah & \multirow{2}{*}{$0,81 \%$} \\
\hline & $52,86 \mathrm{~m}^{2}$ & \\
\hline \multirow{2}{*}{ Lubang } & 43 buah & \multirow{2}{*}{$5,38 \%$} \\
\hline & $349,56 \mathrm{~m}^{2}$ & \\
\hline \multirow{2}{*}{ Tambalan } & 18 buah & \multirow{2}{*}{$4,85 \%$} \\
\hline & $314,80 \mathrm{~m}^{2}$ & \\
\hline Pelepasan Butir & $184,44 \mathrm{~m}^{2}$ & $2,84 \%$ \\
\hline Kegemukan & $226,80 \mathrm{~m}^{2}$ & $3,49 \%$ \\
\hline \multirow{2}{*}{ Amblas } & 12 buah & \multirow{2}{*}{$2,38 \%$} \\
\hline & $154,60 \mathrm{~m}^{2}$ & \\
\hline
\end{tabular}

Sumber: Survey Lapangan, 2020
Available online at www.jurnal.borneo.ac.id Halaman 07-17

\section{Tabel 7. Hasil Survey Identifikasi Kondisi Sisi Kanan Jalan Gajah Mada}

\begin{tabular}{|c|c|c|}
\hline Tipe Kerusakan & $\begin{array}{c}\text { Volume } \\
\text { kerusakan }\end{array}$ & $\begin{array}{c}\text { Prosentase } \\
\text { Iuas kerusakan } \\
\text { dari luas Jalur } \\
\left(6.496 \mathrm{~m}^{2}\right)\end{array}$ \\
\hline $\begin{array}{l}\text { Retak Kulit Buaya } \\
(\text { lebar }>2 \mathrm{~mm})\end{array}$ & $146,80 \mathrm{~m}^{2}$ & $2,26 \%$ \\
\hline $\begin{array}{l}\text { Retak Memanjang / } \\
\text { Retak Pinggir } \\
(\text { lebar }>2 \mathrm{~mm})\end{array}$ & $243,64 \mathrm{~m}^{2}$ & $3,75 \%$ \\
\hline $\begin{array}{l}\text { Retak Melintang } \\
(\text { lebar }>2 \mathrm{~mm})\end{array}$ & $194,18 \mathrm{~m}^{2}$ & $2,99 \%$ \\
\hline $\begin{array}{l}\text { Retak Acak } \\
(\text { lebar }>2 \mathrm{~mm})\end{array}$ & $282,46 \mathrm{~m}^{2}$ & $4,35 \%$ \\
\hline \multirow{2}{*}{$\begin{array}{l}\text { Alur (kedalaman } 11 \text { - } \\
20 \mathrm{~mm} \text { ) }\end{array}$} & 11 buah & \multirow{2}{*}{$1,30 \%$} \\
\hline & $84,24 \mathrm{~m}^{2}$ & \\
\hline \multirow{2}{*}{ Lubang } & 44 buah & \multirow{2}{*}{$4,38 \%$} \\
\hline & $284,26 \mathrm{~m}^{2}$ & \\
\hline \multirow{2}{*}{ Tambalan } & 24 buah & \multirow{2}{*}{$7,16 \%$} \\
\hline & $464,80 \mathrm{~m}^{2}$ & \\
\hline Pelepasan Butir & $214,20 \mathrm{~m}^{2}$ & $3,30 \%$ \\
\hline Kegemukan & $148,40 \mathrm{~m}^{2}$ & $2,28 \%$ \\
\hline \multirow{2}{*}{ Amblas } & 8 buah & \multirow{2}{*}{$1,48 \%$} \\
\hline & $96,44 m^{2}$ & \\
\hline
\end{tabular}

Sumber: Survey Lapangan, 2020

\section{d. Penilaian Kerusakan Jalan Dengan Metode Bina Marga}

Penilaian kondisi jalan dengan menganalisis data yang telah diperoleh dari survey yang telah dilaksanakan seperti survey kondisi jalan dan survey lalu lintas.

\section{Penentuan Nilai Kelas Lalu Lintas}

Penentuan nilai kelas lalu lintas berdasarkan data lalu lintas harian ratarata (LHR) yang telah disajikan pada Tabel 5, diperoleh sebesar 3.301 smp/hari, kemudian dikorelasikan dengan Tabel 2, sehingga diperoleh nilai kelas Jalan Gajah Mada adalah 5.

\section{Penentuan Tingkat Kerusakan Jalan}

Perhitungan angka kerusakan terhadap data kerusakan jalan yang telah dikompilasi, dianalisis dengan mengacu pada hasil penelitian Bolla (2012) dan Saputro (2014). Untuk jenis kerusakan retak, angka kerusakan 
JURNAL BORNEO SAINTEK

Volume 3, Nomor 1, April 2020

e-ISSN 2599-3313

p-ISSN 2615-434X

dipertimbangkan dari jenis retak, lebar retak dan luas keretakannya, dimana untuk nilai kelompok retak digunakan adalah angka terbesar dari ketiga komponen retak tersebut. Sedangkan untuk kelompok kekasaran permukaan, lubang dan tambalan, didasarkan pada jenis kerusakan saja.
Available online at www.jurnal.borneo.ac.id Halaman 07-17

Tabel 8. Penilaian Tingkat Kerusakan Jalan Sisi Kiri Jalan Gajah Mada

\begin{tabular}{|c|c|c|c|c|c|c|}
\hline \multirow{2}{*}{ Jenis Kerusakan } & \multicolumn{5}{|c|}{ Penilaian Tingkat Kerusakan } & \multirow{2}{*}{$\begin{array}{c}\text { Angka } \\
\text { Kerusakan }\end{array}$} \\
\hline & Tipe & Lebar & Luas & Kedalaman & Panjang Amblas & \\
\hline Retak Kulit Buaya & 5 & 3 & - & - & - & 5 \\
\hline Retak Memanjang & 1 & 3 & - & - & - & 3 \\
\hline Retak Melintang & 3 & 3 & - & - & - & 3 \\
\hline Retak Acak & 4 & 3 & - & - & - & 4 \\
\hline Alur & - & - & - & 3 & - & 3 \\
\hline Tambalan \& Lubang & - & - & 1 & - & - & 1 \\
\hline Pelepasan Butir & 3 & - & - & - & - & 3 \\
\hline Kegemukan & 1 & - & - & - & - & 1 \\
\hline Amblas & - & - & - & - & 1 & 1 \\
\hline & & tal Angk & Kerusal & & & 24 \\
\hline
\end{tabular}

Sumber: Analisis Data, 2020

Tabel 9. Penilaian Tingkat Kerusakan Jalan Sisi Kanan Jalan Gajah Mada

\begin{tabular}{|c|c|c|c|c|c|c|}
\hline \multirow{2}{*}{ Tipe Kerusakan } & \multicolumn{5}{|c|}{ Penilaian Tingkat Kerusakan } & \multirow{2}{*}{$\begin{array}{c}\text { Angka } \\
\text { Kerusakan }\end{array}$} \\
\hline & Jenis & Lebar & Luas & Kedalaman & Panjang Amblas & \\
\hline Retak Kulit Buaya & 5 & 3 & - & - & - & 5 \\
\hline Retak Memanjang & 1 & 3 & - & - & - & 3 \\
\hline Retak Melintang & 3 & 3 & - & - & - & 3 \\
\hline Retak Acak & 4 & 3 & - & - & - & 4 \\
\hline Alur & - & - & - & 5 & - & 5 \\
\hline Tambalan \& Lubang & - & - & 1 & - & - & 1 \\
\hline Pelepasan Butir & 3 & - & - & - & - & 3 \\
\hline Kegemukan & 1 & - & - & - & - & 1 \\
\hline Amblas & - & - & - & - & 1 & 1 \\
\hline & & angk & Kerus & kan & & 26 \\
\hline
\end{tabular}

Sumber: Analisis Data, 2020

\section{Nilai Kondisi Jalan}

Nilai tingkat kerusakan sisi kiri ruas jalan Gajah Mada sebesar 24, berdasarkan Tabel maka kondisi jalan diperoleh nilai 8, sedangkan jalan sisi kanan dengan nilai tingkat kerusakan sebesar 26 diperoleh nilai kondisi jalan 9.

\section{Urutan Prioritas}

Perhitungan urutan prioritas masingmasing sisi jalan dengan menggunakan
Untuk retak alur, angka kerusakan didasarkan pada besar kedalaman alur yang terjadi, sedangkan untuk amblas angka kerusakan didasarkan pada panjang amblas per 100 meter.

Penilaian tingkat kerusakan masingmasing sisi ruas Jalan Gajah Mada di tampilkan pada Tabel 8 dan Tabel 9. persamaan sebagai berikut:

$$
\begin{aligned}
\mathrm{UP}_{(\text {sisi kiri })}= & 17-(\text { Kelas LHR }+ \text { Kondisi } \\
& \text { Jalan }) \\
= & 17-(5+8) \\
= & 4 \\
U_{(\text {sisi kanan })=} & 17-(\text { Kelas LHR }+ \text { Kondisi } \\
& \text { Jalan }) \\
= & 17-(5+9) \\
= & 3
\end{aligned}
$$


JURNAL BORNEO SAINTEK

Volume 3, Nomor 1, April 2020

e-ISSN 2599-3313

p-ISSN 2615-434X

5. Penentuan Program Pemeliharaan

Berdasarkan analisis yang telah dilaksanakan bahwa diperoleh nilai Urutan Prioritas (UP) untuk sisi kiri nilai 4 dan sisi kanan nilai 3, maka berdasarkan Tata Cara Penyusunan Program Pemeliharaan Jalan Kota No. 018/T/BNKT/1990, program pemeliharaan yang direkomendasikan adalah program pemeliharaan berkala untuk sisi kiri dan untuk sisi kanan masuk kedalam program peningkatan jalan atau rehabilitasi jalan.

Memperhatikan peran dari Jalan Gajahmada yang sangat penting sebagai akses utama menuju kawasan perniagaan Pasar Gusher dan Pelabuhan Tengkayu II kota Tarakan, maka untuk memberikan kinerja jalan yang optimal direkomendasikan penanganan preservasi ruas jalan tersebut dengan program peningkatan jalan berupa kegiatan penambahan lapis permukaan perkerasan (overlay).

\section{KESIMPULAN}

Berdasarkah hasil analisis yang telah dilakukan dapat dibuat kesimpulan sebagai berikut:

1. Jenis kerusakan yang terjadi pada ruas Jalan Gajah Mada Kota Tarakan ada 9 macam tipe kerusakan yaitu: kerusakan retak kulit buaya seluas $571,00 \mathrm{~m}^{2}$ dengan persentase luas kerusakan mencapai $8,79 \%$ dari total luas segmen jalan, berikutnya kerusakan retak memanjang/retak pinggir $\left(879,00 \mathrm{~m}^{2}, 7,05 \%\right)$, retak melintang $\left(380,36 \mathrm{~m}^{2}, 5,86 \%\right)$, retak acak $\left(514,80 \mathrm{~m}^{2}, 7,93 \%\right)$, alur $(137,10$ $\left.\mathrm{m}^{2}, 2,11 \%\right)$, tambalan dan lubang $\left(1.413,42 \mathrm{~m}^{2}, 21,77 \%\right)$, pelepasan butir $\left(398,64 \mathrm{~m}^{2}, 6,14 \%\right)$, kegemukan $\left(375,20 \mathrm{~m}^{2}, 5,57 \%\right)$, dan amblas $\left(251,04 \mathrm{~m}^{2}, 3,86 \%\right)$.

2. Perhitungan nilai kondisi jalan hasil pengamatan pada Jalan Gajah Mada Kota Tarakan dengan metode Bina Marga diperoleh urutan prioritas 4 untuk penanganan jalan pada sisi kiri
Available online at www.jurnal.borneo.ac.id

Halaman 07-17 sehingga masuk program pemeliharaan berkala, dan urutan prioritas 3 penanganan jalan pada sisi kanan sehingga masuk program pemeliharaan peningkatan atau rehabilitasi jalan.

3. Usulan perbaikan dari hasil studi ini dengan mempertimbangkan peran strategis dari Jalan Gajah Mada dalam menunjang aksesibilitas kegiatan perekonomian di kawasan perniagaan kota Tarakan maka direkomendasikan program peningkatan jalan berupa kegiatan penambahan lapis permukaan perkerasan (overlay).

\section{DAFTAR PUSTAKA}

Bakri, M.D., 2019. Evaluasi Kondisi dan Kerusakan Perkerasan Lentur Dengan Metode Pavement Condition Index (PCI) (Studi Kasus: Jalan Gunung Selatan Kota Tarakan Provinsi Kalimantan Utara). Borneo Engineering Jurnal Teknik Sipil Vol.3 No. 2 Desember 2019, hal. 81-96, ISSN: 2581-1134.

Bolla, M.E., 2012. Perbandingan Metode Bina Marga dan Metode PCI (Pavement Condition Index) Dalam Penilaian Kondisi Perkerasan Jalan (Studi Kasus Ruas Jalan Kaliurang, Kota Malang). Jurnal Teknik Sipil Universitas Nusa Cendana Vol. 1 No. 3 April 2012, hal. 104-116, ISSN: 2089-4953.

Daryoto, Widodo. S., Mayuni, S., 2015. Studi Kondisi Permukaan Jalan Pada Lapis Permukaan Dengan Menggunakan Metode Bina Marga (Studi Kasus Ruas Jalan Harapan Raya Kota Pontianak). Jurnal Mahasiswa Teknik Sipil Universitas Tanjung Pura Vol. 2 No. 2 Juni 2015.

Dinas Pekerjaan Umum dan Tata Ruang Kota Tarakan. 2015. Daftar Data Jalan Kota Tarakan. Tarakan.

Direktorat Jenderal Bina Marga Depatemen Pekerjaan Umum Republik Indonesia. 1990. Petunjuk Teknis Perencanaan dan Penyusunan 
JURNAL BORNEO SAINTEK

Volume 3, Nomor 1, April 2020

e-ISSN 2599-3313

p-ISSN 2615-434X

Program Jalan Kabupaten No. 77/KPTS/Db/1990. Jakarta.

Direktorat Jenderal Bina Marga Depatemen Pekerjaan Umum Republik Indonesia. 1995. Manual Pemeliharaan Rutin Untuk Jalan Nasional dan Provinsi No. 001/T/Bt/1995 Metode Survei. Jakarta.

Direktorat Jenderal Bina Marga Depatemen Pekerjaan Umum Republik Indonesia. 1995. Manual Pemeliharaan Rutin Untuk Jalan Nasional dan Provinsi No. 002/T/Bt/1995 Metode Perbaikan Standar. Jakarta.

Direktorat Pembinaan Jalan Kota Direktorat Jenderal Bina Marga Departemen Pekerjaan Umum Republik Indonesia. 1990. Tata Cara Penyusunan Program Pemeliharaan Jalan Kota No. 018/T/BNKT/1990. Jakarta.

Menteri Pekerjaan Umum Republik Indonesia. 2011. Peraturan Menteri Pekerjaan Umum Republik Indonesia Nomor: 13/PRT/M/2011 Tentang Tata Cara Pemeliharaan Jalan dan Penilikan Jalan. Jakarta.
Available online at www.jurnal.borneo.ac.id

Halaman 07-17

Saputro, D.A., 2014. Perbandingan Evaluasi Tingkat Kerusakan Jalan Dengan Metode Bina Marga dan Metode Paver (Studi Kasus Kecamatan Kepanjen Kabupaten Malang dan Sekitarnya). Jurnal SISTEM Vol. 10 No. 3 Desember 2014, hal. 10-20.

Suwandi, A., Guswandi., Armada. 2018. Analisa Kerusakan Jalan Wonosari Kecamatan Bengkalis dengan Metode Pavement Condition Index (PCI) dan Bina Marga (Studi Kasus Jalan Wonosari Barat, Jalan Wonosari Timur, Jalan Wonosari Tengah, Jalan Baru Wonosari). Prosiding Seminar Nasional Industri dan Teknologi (SNIT) Politeknik Negeri Bengkalis, Oktober 2018, hal. 325-329.

Wicaksono, M.F.B., Mahardi, P., 2018. Analisis Nilai Kondisi Perkerasan Jalan Secara Visual Dengan Metode Bina Marga dan Pavement Condition Index Studi Kasus: Jalan Mastrip (SBY 10+100 - 10+700). Jurnal Rekayasa Teknik Sipil Vol. 3 No. 3 Tahun 2018, ISSN: 2252-5009. 
